\title{
It is not just about the ice: a geochemical perspective on the changing Arctic Ocean
}

\author{
R. W. Macdonald ${ }^{1,2} \cdot$ Z. A. Kuzyk ${ }^{2}$ - S. C. Johannessen ${ }^{1}$ \\ Published online: 16 July 2015 \\ (C) The Author(s) 2015. This article is published with open access at Springerlink.com
}

\begin{abstract}
Much concern has accompanied the dramatic decrease in area covered by permanent pack ice in the Arctic Ocean during the past two decades. Ice is undeniably the most obvious feature distinguishing the Arctic Ocean, and its loss seizes public and scientific attention like no other tipping point. Beneath that challenging ice surface lies an ocean that is strongly affected by other less-visible factors that also have a large say in how change will occur in this ocean. Especially important to the Arctic Ocean is its connection to the surrounding land, which feeds it fresh water and organic carbon, and the large shelves and enclosed geography that accentuate the importance of these external factors. Like the sea ice, land is changing rapidly due to widespread thawing of permafrost. For the three global risks that have been deeply thought about recently in the context of Arctic Ocean ecosystems (i.e. contaminants, warming, ocean acidification), the Arctic appears to be exceptionally sensitive, sufficiently so that it has been termed a bellwether for each. Here, we examine how the lessvisible factors (fresh water, organic carbon cycling) affect the Arctic's reception of risk and its potential to export risk to the rest of the globe. We conclude that there needs to be a better coordinated effort to collect time series for the terrestrial
\end{abstract}

R. W. Macdonald

Robie.Macdonald@dfo-mpo.gc.ca

Z. A. Kuzyk

zouzou.kuzyk@umanitoba.ca

S. C. Johannessen

sophia.johannessen@dfo-mpo.gc.ca

1 Department of Fisheries and Oceans, Institute of Ocean Sciences, PO Box 6000, Sidney, BC, Canada V8L 4B2

2 Centre for Earth Observation Science and Department of Geological Sciences, University of Manitoba, Winnipeg, MB, Canada R3T 2 N2 components cycling within the Arctic Ocean such that we can understand what is happening to the marine components.

Keywords Arctic Ocean $\cdot$ Change $\cdot$ Fresh water $\cdot$ Organic carbon

\section{Introduction}

There is no doubt that the Arctic Ocean is undergoing change. If you ask the public or arctic scientists what constitutes that change, both groups would most likely answer first that the sea ice is disappearing. Once that is agreed upon, the discussion of the significance of vanishing ice provokes differing views. For the public, it is the uncertain future faced by polar bears and other charismatic animals; for people who live in the north, it is threats to culture, health, food security and travel; and for scientists, it is feedbacks that affect not only the function of the Arctic but also the potential for Arctic change to impact global systems. All of these topics have merit and urgency.

Numerous articles in the popular press and the scientific literature during the past two decades have focussed, almost obsessively, on the ongoing decline in the Arctic's sea ice. Although most of these articles present the loss of ice as a disaster unfolding, some propose that more open water provides opportunities for exploration, exploitation and transport and, with these, challenges to sovereignty. These notions, which tie the loss of ice to sustainable development of renewable and non-renewable Arctic resources (i.e. economics), technological advancement, management and governance, have clinched Arctic sea-ice loss as a topic of immediate regional, national and international relevance.

The obvious visibility of sea ice, which is the face of the Arctic Ocean, deflects attention away from other features of 
this ocean that are not as visible, but are assuredly as critical for understanding the changes faced by this region. A biogeochemist would find the Arctic Ocean unique among world oceans, with unique vulnerabilities, whether or not there was any sea ice. In this paper, we will take the position that other factors - fresh water runoff and terrigenous organic carbon-play equally critical roles on the Arctic Ocean stage. The approach that we will follow here, therefore, will be first to discuss the salient oceanographic features that make the Arctic Ocean what it is, and from there discuss the biogeochemical changes faced by this ocean.

\section{Fresh water-the significance of runoff, precipitation and ice melt in the Arctic Ocean}

To an ocean scientist, the hydrological cycle begins at the estuary, and nowhere is this more true than in the Arctic Ocean, which itself may be viewed as a grand estuary (McClelland et al. 2012). Because it receives only $11 \mathrm{~cm}$ year $^{-1}$ of precipitation, the Arctic Ocean qualifies as a desert. Nevertheless, the $2000 \mathrm{~km}^{3}$ year $^{-1}$ of direct precipitation is augmented by a further $\sim 3300 \mathrm{~km}^{3}$ year $^{-1}$ of fresh water that flows into the ocean's margin from four large rivers (Lena, Ob, Yenisei, Mackenzie) and numerous smaller ones (Figs. 1 and 2). As this fresh water circulates and passes through the Arctic Ocean, it produces a low density surface layer ( $<50 \mathrm{~m}$ thick) often referred to as the polar mixed layer (PML) (Fig. 3). The Arctic Ocean is also a conduit through which $\sim 2500 \mathrm{~km}^{3}$ year ${ }^{-1}$ excess fresh water from the Pacific Ocean is able to return to the Atlantic, thus maintaining a longterm balance in the global fresh water cycle (e.g. see Wijffels et al. 1992). Not all the seawater has the same salinity or density, and waters of different densities do not mix easily. Consequently, various water masses enter the Arctic Ocean at different depths, then find their place among the layered, or stratified, waters (Fig. 2). Pacific water that enters through Bering Strait is less dense than that which comes into the Arctic Ocean from the Atlantic side. However, some of this Pacific water becomes modified by processes shortly after it enters the Arctic Ocean, becoming slightly more dense by cooling and the addition of brine from ice production over the Chukchi Sea in winter. These changes force it below the Arctic Ocean's surface layer (PML) where it forms a layer of cold salty water termed a halocline because salt content increases with depth (Fig. 3, Pacific Halocline (50-300 m)). Over on the Atlantic side, the densest (saltiest) water enters the Arctic Ocean. Seasonal cycling of the surface water, which includes mixing of sea-ice melt, cooling and the addition of brine to this Atlantic water in the Barents Sea (Rudels 2015), also causes surface water to subduct under the Arctic Ocean surface layer forming the Atlantic Halocline (Fig. 2), further reinforcing salt stratification. These large-scale processes lead to a robust salinity stratification throughout the Arctic Ocean where each layer is progressively denser with depth (Fig. 3). Stratification is the single most important control for how the Arctic Ocean can respond to forcing from inside or outside the Arctic.

It takes time for fresh water to pass through the Arctic Ocean. In Fig. 2, the stored fresh water $\left(75,000 \mathrm{~km}^{3}\right)$, divided by the inputs $\left(\sim 7100 \mathrm{~km}^{3}\right.$ year $\left.{ }^{-1}\right)$ implies a freshwater residence time of about 10 years (Östlund 1982). The fresh water storage performs three crucial tasks. First, the fresh water at the surface in the interior Arctic Ocean (PML, haloclines) acts as a lid that prevents mixing between deep and surface waters. One result is the rich supply of nutrients in deep waters cannot be brought up into the light to support photosynthesis (primary production). The Arctic Ocean basins, therefore, have a perennially low productivity, which is evident in the exceptionally small rain of biogenic particles out of the surface layer (Honjo et al. 2010). The low productivity in the interior regions might intuitively be blamed on the shade produced by ice and snow cover, but it is more likely that the stratification starves the surface of nutrients, and that the interior Arctic Ocean would remain unproductive were the ice to be removed. Second, the fresh water lid prevents the return of heat to the surface from the deeper Atlantic Layer (Fig. 3) where there resides a large reservoir of water above the freezing temperature of ice, thus permitting sea ice to form and persist. Third, the lid acts a barrier to the sinking of water made dense through sea-ice formation (thermohaline circulation). When the surface ocean freezes, sea ice rejects much of the salt as brine, which then accumulates in the surface water. Brine makes the water more dense, but when there is a lot of fresh water, the brine cannot make the surface water dense enough to sink. Consequently, the brine rejected by sea-ice growth produces a surface mixed layer (PML) but does not bring about deep convection except in special areas to be discussed below. Within this general picture, the intensity of stratification varies depending on how fresh water is distributed at any given time, which implies that nutrient resupply and halocline maintenance likewise vary (Boyd et al. 2002; Johnson and Polyakov 2001; Macdonald et al. 1999; Nishino et al. 2008).

Stored fresh water also provides an important mechanism by which the Arctic Ocean could affect global climate. When such water is exported rapidly into the North Atlantic Ocean, it must pass by important convecting sites where deep, ventilating water is produced. If a portion of this fresh water becomes mixed into the surface of the convecting sites during this process (Aagaard and Carmack 1989), there becomes a risk of impeding convection in the North Atlantic through stratification (Broecker 2006). It remains a point of debate on the relative importance of ice or liquid fresh water export in providing such stratification, but there is strong evidence that rapid release of fresh water due to an outburst from glacial Lake Agassiz may have caused a climatically important 
Fig. 1 The Arctic Ocean showing the large drainage basins, the large river inflows and the large shelves. The arrow in the inset box shows the arrow width corresponding to $200 \mathrm{~km}^{3}$ year ${ }^{-1}$ inflow

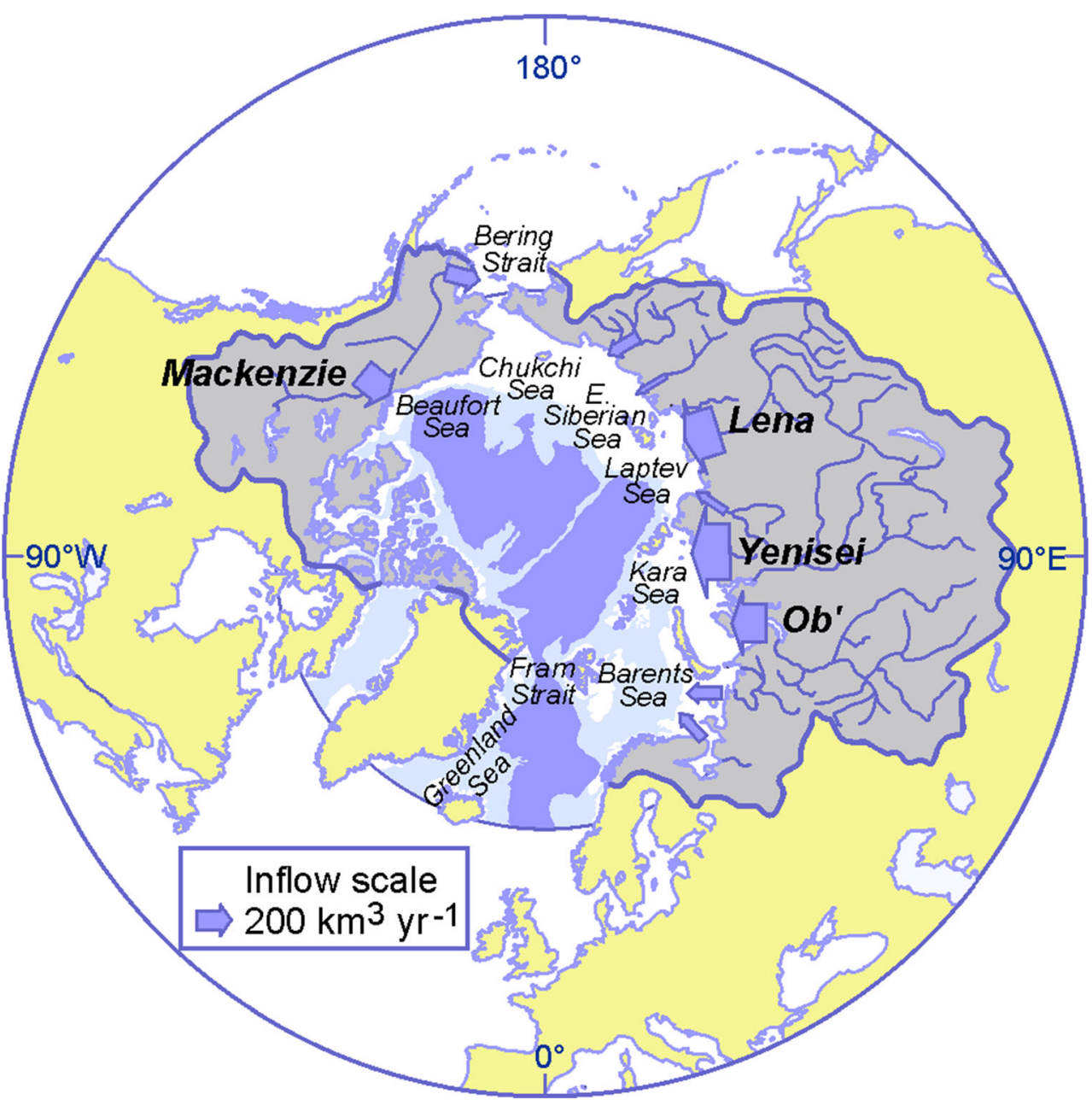

cooling event at the end of the last ice age (Younger Dryas (see, for example, Murton et al. 2010)). The important question here is how much fresh water could the Arctic Ocean store (liquid or solid), and how quickly could it be released.

Moving fresh water performs two very different tasks. First, the runoff component of fresh water brings with it a supply of nutrients $\left(\mathrm{Si}(\mathrm{OH})_{4}, \mathrm{~N}, \mathrm{P}\right)$ from land, which then contribute to shelf productivity. A common misconception is that this nutrient supply from rivers is the major cause of phytoplankton productivity in estuaries. When rivers flow into the sea, they mix partially with the salt water beneath, dragging nutrientrich water up to the surface as they pass through the estuary and out across the shelf (Fig. 4) (e.g. see Gordon et al. 1996). For Arctic Ocean productivity, this estuarine circulation is far more important than river inflow (Macdonald et al. 2010).

What is important, therefore, is the contrast between moving fresh water, which promotes the return of deep-water properties to the surface, and stored fresh water, which

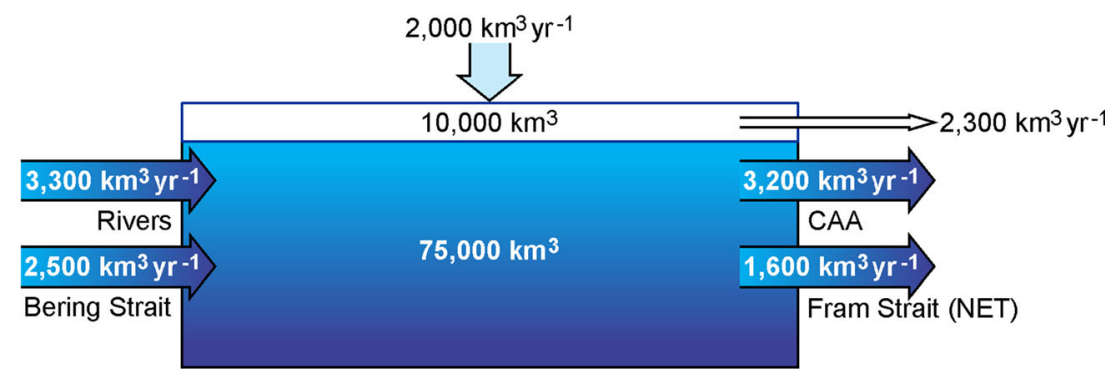

Fig. 2 A simplified fresh water budget of the Arctic Ocean (based on Serreze et al. 2006). The blue arrows to the left show the inputs of fresh water to the Arctic Ocean, the top arrow shows net precipitation and the arrows to right show the major outflows of fresh water via Fram Strait

(net outflow) and the Canadian Arctic Archipelago (CAA). Ice, shown in white, also provides a reservoir of fresh water and a means of export from the Arctic Ocean 


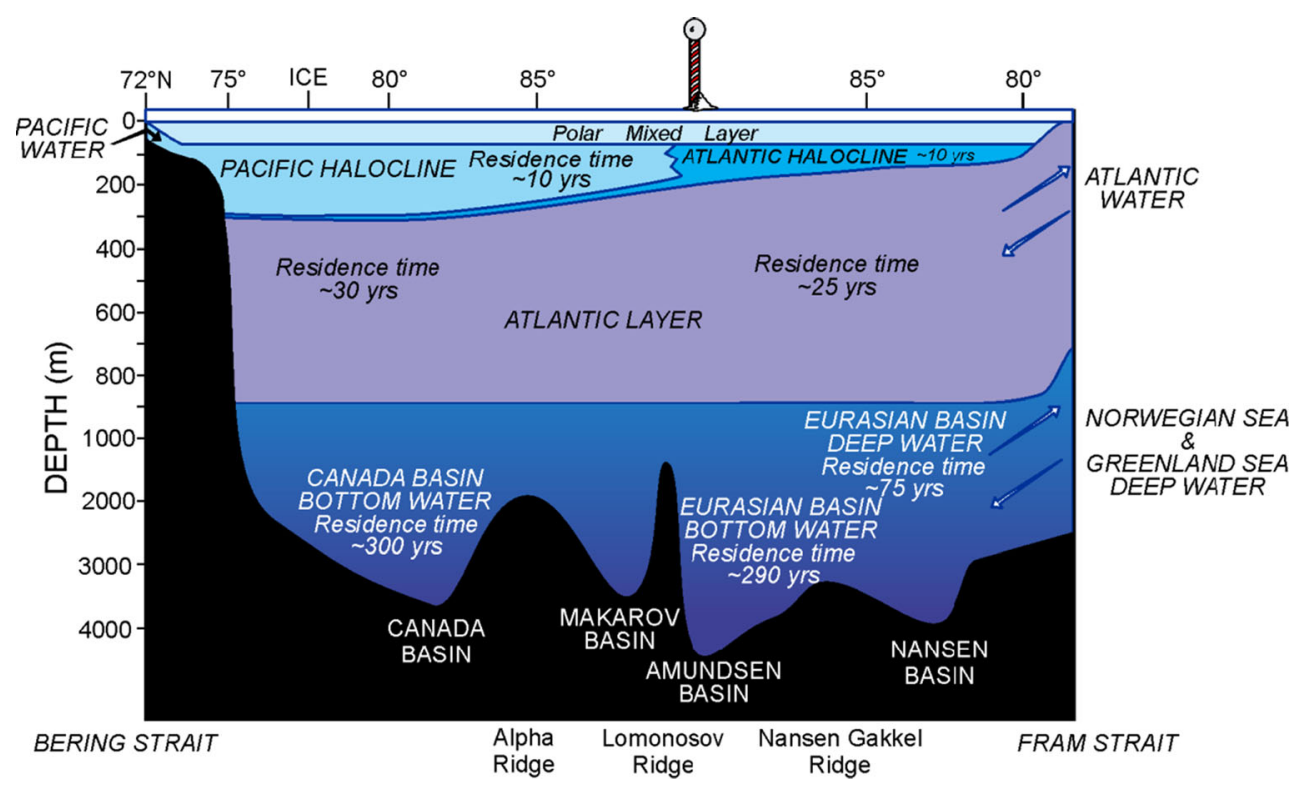

Fig. 3 A schematic diagram of the vertical structure of the water column in the Arctic Ocean (adapted from (Macdonald et al. 2005), which is organized by density stratification into a surface layer (polar mixed layer) beneath which is cold water of increasing salinity with depth (halocline). The halocline provides a strong separation between the surface layers and the

prevents it (Fig. 4). Moving fresh water tends to be associated with runoff over the shelves, whereas stored fresh water is associated with runoff, precipitation and ice melt in the basins (Fig. 4). Therefore, a component of change in the Arctic Ocean has to do almost entirely with details in the hydrological cycle.

\section{The size of the Arctic watersheds}

The Arctic Ocean has a watershed $\left(\sim 23 \times 10^{6} \mathrm{~km}^{2}\right)$ that is over twice the Arctic Ocean's surface area $\left(10 \times 10^{6} \mathrm{~km}^{2}\right)$. Whatever else goes on within the Arctic Ocean, we can never neglect the land that surrounds it. The semi-enclosed geography of the Arctic Ocean (Fig. 1) magnifies the terrestrial effect. Much of the drainage basin, especially for large rivers, warmer Atlantic layer, such that sea ice may form across the ocean. Approximate time frames for replacement of the water in the various layers have been compiled in a number of publications including Macdonald et al. (1993), Östlund (1982), Schlosser et al. (1994a, b), Smith et al. (2011) and Yamamoto-Kawai et al. (2008)

extends south into temperate zones and is not arctic at all. These drainages span regions dominated by permafrost to regions that have no permafrost, and wide varieties of vegetation (tundra, low shrubs, wetlands, boreal forest, grasslands). As we will see, the land imparts a pervasive terrigenous imprint to the Arctic Ocean's organic cycle.

\section{The enormous size of the continental shelves}

Shelves, defined as the coastal regions out to 150-200 m water depth, comprise fully one half of the Arctic Ocean's area (Fig. 1 and 5). The extraordinary proportion of the shelf in the Arctic Ocean can be seen by comparison to the typical $20 \%$ shelf area in the global ocean (Fig. 5). Much of the Arctic Ocean is, therefore, a set of connected shallow-sea shelves.

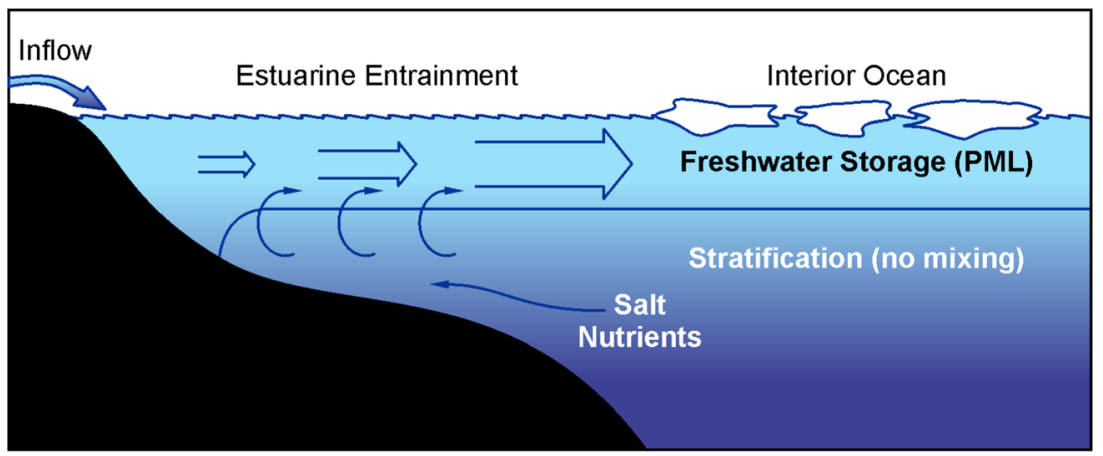

Fig. 4 Estuarine entrainment and storage in the Arctic Ocean. Upon entering the ocean, runoff transports across the shelves becoming saltier along the way by entraining water from beneath, which brings nutrients to the surface. Within the interior ocean, much of the fresh water is stored in the polar mixed layer (PML), which prevents nutrients from getting to the surface 


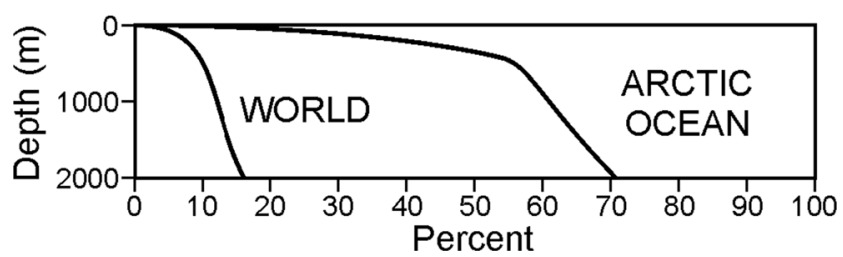

Fig. 5 The distribution of bottom depth in the world ocean and Arctic Ocean. The extension of shallow regions out to $50 \%$ area in the Arctic indicates the dominance of shelves

Due to their size ( $<100$ to $>1000 \mathrm{~km}$ wide), these shelves act as individual connected seas, storing sediments and fresh water, metabolizing and burying terrigenous carbon, supporting primary production, producing and melting ice, and processing water, which they then export to the Arctic Ocean interior. No shelf in the Arctic is a proxy for another shelf, and it is the shelf areas that will be the key to how change affects humans who occupy their shores.

\section{Sea ice in the context of fresh water and shelves}

Sea ice forms an important reservoir $\left(\sim 10,000 \mathrm{~km}^{3}\right)$ and export pathway $\left(2300 \mathrm{~km}^{3}\right.$ year $\left.{ }^{-1}\right)$ for fresh water in the Arctic Ocean (Fig. 2). Melting sea ice during summer adds brackish water to the ocean surface, enhancing stratification, whereas producing sea ice in winter adds brine to the ocean surface making it denser, which can lead to mixing and/or convection. Based on geochemical data, we find that the effect of sea ice on fresh water in the Arctic Ocean is fundamentally different from that of runoff, and this needs to be clearly understood before we can project what change in stratification might mean. Runoff and precipitation are perennial suppliers of stratification from outside the Arctic Ocean, the same as any other ocean. Runoff has an exceptionally strong, synchronous seasonal cycle that varies from year to year (a lot), and exhibits long-term change in the timing and amounts of inflow (e.g. see Lewis et al. 2000; Peterson et al. 2002).

Sea-ice formation and melting are more complicated than runoff. Sea ice produces a seasonal cycle within the ocean's hydrology; the melting of sea ice in summer produces a brackish surface layer on top of the previous winter's mixed layer (Fig. 6a, left panel) whereas the freezing of sea ice in winter leaves salt behind in the ocean, which then destroys that stratification by mixing the surface water and reforming the PML (Fig. 6a, right panel). At the annual scale, this is a 'do-nothing' process. However, sea-ice formation can have another outcome when a lot of ice is produced - enough to make the surface water dense enough to sink to deeper depths (Fig. 6b, right panel). In the Arctic, this process is key to supplying new salty water to the cold haloclines and therefore maintaining them (Aagaard et al. 1985). The crucial point about the sinking of this dense briny water is that salt and fresh water from sea-ice melt are separated more permanently, unlike the usual annual cycle, and therefore contribute to greater stratification of the Arctic Ocean.

Sea ice provides a formidable storage reservoir (Fig. 2 $\left.\left(10,000^{+} \mathrm{km}^{3}\right)\right)$. The loss of this reservoir through recent melting, therefore, contributes to the supply of fresh water held by the ocean surface. Unlike runoff, however, this process is not indefinitely sustainable; specifically, the maximum contribution would be about $10,000 \mathrm{~km}^{3}$ if all the sea ice were to melt.

The geography of the Arctic Ocean (large shelves) is crucially important to how the ice interacts with the hydrological cycle. Broadly speaking, we find three types of ice: landfast, first year/seasonal and multi-year pack ice. Landfast ice extends out to about the 20-m water depth. Beyond that, out over the shelves, seasonal ice predominates, while in the interior ocean, especially north of the Canadian Arctic Archipelago, multi-year ice predominates. Ice is self-insulating, with the result that the thicker the ice, the more slowly it grows (Anderson 1961). Thus, multi-year ice (>3 m) is sluggish in adding new ice at the bottom of the pack in winter, especially if it is covered by an insulating snow layer, and therefore has little chance to produce convecting water by overwhelming the fresh water stored in the mixed layer. We can easily illustrate this with a 'back of the envelope' estimate. Consider, for example, that half of the inventory of fresh water stored in the Arctic Ocean $\left(37,000 \mathrm{~km}^{3}\right)$ resides in the polar mixed layer (Fig. 3). The area of the Arctic Ocean, $10 \times 10^{6} \mathrm{~km}^{2}$, implies that about $3.7 \mathrm{~m}$ of fresh water would be contained within the 40-50-m PML on average. Multi-year pack ice has no hope of growing $3.7 \mathrm{~m}$ of ice during winter, which would be the minimum required to remove this fresh water from the mixed layer, let alone growing even more ice to make the water in the PML dense enough to sink to deeper depths.

Seasonal ice can grow to about $2 \mathrm{~m}$ in winter, and thus remove more fresh water than multi-year ice. That amount of growth is, still, not generally sufficient to balance out the runoff, precipitation and sea-ice melt water accumulated at the surface by the end of summer. The result is simply a reestablishment of the mixed layer by the end of winter. Landfast ice also has a hard time forcing convection because of the concentration of fresh water near the shore (Macdonald 2000). These rough calculations illustrate how important fresh water storage is in deciding the hydrological function of sea ice in the Arctic Ocean. The most effective locations to produce sinking water in the Arctic Ocean, and thereby augment stratification, are the mid-shelves where there is a network of flaw-leads or gaps of open water during winter (Fig. 7). The mid-shelves may shed ice cover in winter when wind blows the ice off shore, and these open areas rapidly refreeze, producing lots of sea ice (Martin et al. 1992). Shelves are the important sites, therefore, where sea ice can produce salt and fresh water separation for periods exceeding the seasonal, and 
Fig. 6 A schematic diagram showing a how the cycle of ice melt (left) and ice freezing (right) operate in a strongly stratified ocean, and $\mathbf{b}$ how these cycles operate when ice production is sufficient to overcome the stratification and thereby export salt below the mixed layer. In the top panels (a), the freeze-melt cycle of sea ice is constrained to the polar mixed layer, which results in strong mixing in winter and stratification by sea-ice melt in summer. In the bottom panels (b), some of the salt rejected during ice formation is injected into deeper water (the arctic haloclines). In the following summer, melt water from the ice cannot remix with the salt with the result that a more permanent stratification is produced
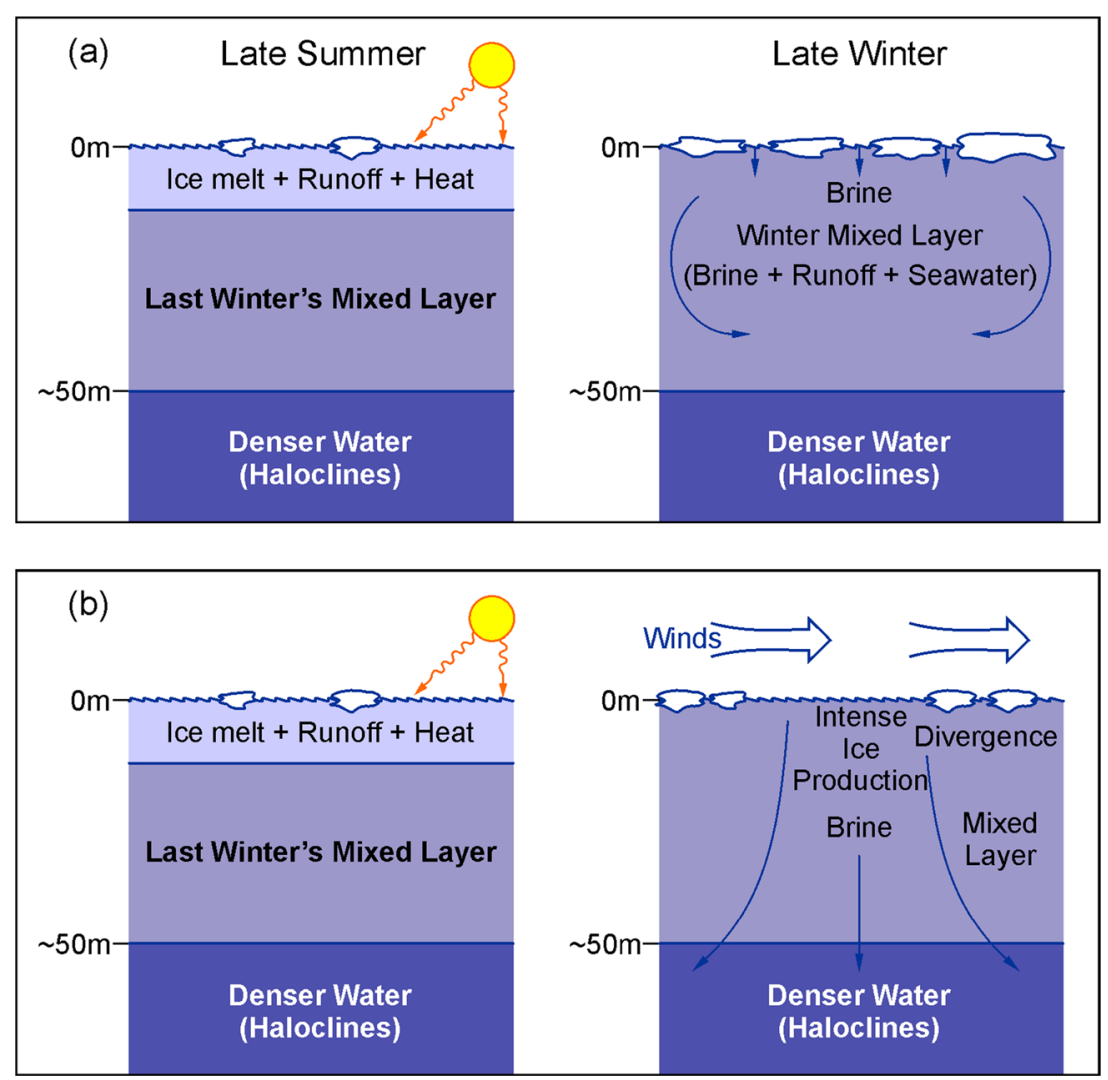

thereby contribute to the general stratification of the Arctic Ocean.

\section{Climate change in the Arctic Ocean}

Change in the Arctic Ocean has been observed in river inflow (McClelland et al. 2006), sea-ice extent (Stroeve et al. 2012), sea-ice thickness (Rothrock et al. 2008), water temperatures (Carmack et al. 2015; Walsh et al. 2011) and fresh water inventory (Polyakov et al. 2013; Rabe et al. 2011), with likely consequences for ecosystems (Post et al. 2013). Change is also occurring in adjacent terrestrial systems (Francis et al. 2009; Hinzman et al. 2005; Schindler and Smol 2006; Smith et al. 2005; Smol and Douglas 2007). It has long been proposed that polar regions are more sensitive to global change than regions to the south (Walsh 1991), largely due to the multiple possibilities inherent in phase change from solid to liquid water. Models and paleo-records agree that the polar regions exhibit a range in temperature that is about double that in temperate or tropical climates. Polar change will continue its progress, possibly at an increasing rate (e.g. see Kerr 2012) due to the positive feedback from replacing highly reflecting sea ice with radiation-absorbing water in summer. But let us look at these changes from a geochemical perspective to see what could happen.

\section{Fresh water in the Arctic Ocean}

Assessing trends in runoff is difficult due to large variability, and therefore requires long (decadal) time series. Between 1964 and 2000, the measured total inflow to the Arctic Ocean (including Hudson Bay/Ungava) increased by about $120 \mathrm{~km}^{3}$ year $^{-1}$ (McClelland et al. 2006). This total increase would support greater estuarine circulation over the shelves and greater fresh water storage in the basins. Compared to the input of fresh water to the Arctic Ocean $\left(7100 \mathrm{~km}^{3} \mathrm{year}^{-1}\right)$, this increase $(1.7 \%$ ) seems very small and would be lost in the system variation. On the other hand, precipitation increases of $50 \%$ are projected for Arctic regions (Bintanja and Selten 2014), which implies an extra $1000 \mathrm{~km}^{3}$ year ${ }^{-1}$ of precipitation and more substantive increases in the river inflow. There are difficulties with the moisture-flux projections, however, because much of the modelled increase may be supported by recycled water evaporated from an ice-free ocean (Bintanja and Selten 2014). 


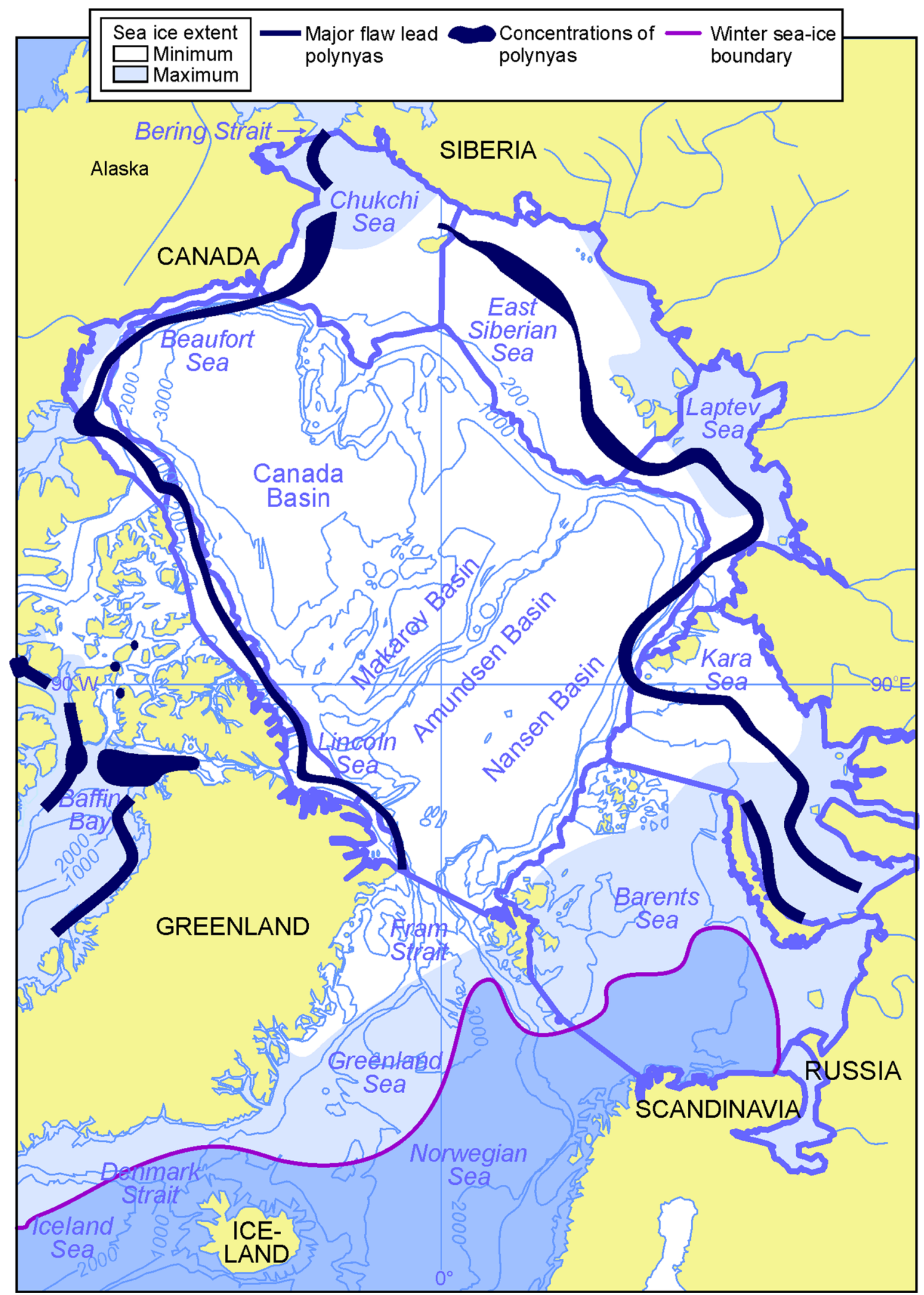

Fig. 7 The Arctic Ocean showing the location of recurrent flaw-leads around the ocean margin. Recurrent polynyas, which are larger regions of open water surrounded by ice, are shown as wider areas of dark blue. The light blue lines define the various shelves that border the Arctic Ocean basins 
What about the sea-ice contribution to the fresh water budget? The minimum sea-ice distribution in late summer for 2012, which so far is the most ice-free year on record, is far below the average minimum extent over the past 40 years since the 1970s (Fig. 8). It is important to understand that since the 1970s there has been a wholesale replacement of $\sim 4$ million $\mathrm{km}^{2}$ of thick multi-year pack ice with thinner, seasonal sea ice (Kwok and Untersteiner 2011). Sea ice regrows every winter, but the large mass of multi-year ice (an important buffer) is being whittled away to be replaced with ice that is thinner, saltier, more difficult to travel over and a different biological habitat. Taken to the limit, the Arctic Ocean could become seasonally clear of ice in late summer. Let us do another 'back of the envelope' calculation. Suppose that an average thickness of multi-year ice $(\sim 4 \mathrm{~m})$ has been replaced by seasonal ice ( $2 \mathrm{~m}$ ) (e.g. see Laxon et al. 2013), and that the replacement has occurred entirely by melting. That is, we will neglect the likely circumstance that a portion of the multi-year ice inventory would have been exported as solid ice. For the area involved, that would be equivalent to the conversion of $\sim 8000 \mathrm{~km}^{3}$ of sea ice to water. Stretched over, say, 2030 years, that would imply at most a supply of 250 $400 \mathrm{~km}^{3}$ year $^{-1}$ of liquid melt water, which is as substantial as the runoff increase. This process, however, spends down 'sea-ice capital' and cannot be sustained. Nevertheless, the multi-year sea-ice reservoir loss cannot be neglected in the early phases of sea-ice demise and must have loaded the Arctic Ocean surface with more fresh water and increasing stratification over the past two decades.

The annual fresh water cycle has likely become more intense. First-year ice produces an annual signal of something like 1.5-2 $\mathrm{m}$ year ${ }^{-1}$ of fresh water, withdrawing this in winter, replacing it with melt water in summer. Multi-year ice exhibits a much smaller cycle $\left(<1\right.$ m year $\left.^{-1}\right)$, and therefore we ought to be seeing more intensive seasonal stratification of the very surface water from ice melt. What is surprising in the image of ice loss (Fig. 8) is that so much of it is occurring on the
Pacific side of the Arctic Ocean. Although this manner of melting out the Arctic Ocean's ice has been explained in hindsight (Carmack et al. 2015; Shimada et al. 2006), back in 1990 most of the science community would have predicted the sea ice on the Atlantic side of the Arctic Ocean as the most vulnerable because of the heat carried by the Atlantic water. Instead, the Atlantic signal is seen as pulses of warm water transporting around the depths within the Atlantic layer (Fig. 3, Polyakov et al. 2013), which does not play into the ice cycle.

What about the sea-ice process of separating salt and fresh water through convection? Change in this process is more difficult to project because the ability of sea-ice formation to produce convecting water depends both on the rate (scale) of ice growth and the inventory of fresh water held at the surface. The mid-shelves will remain as important sites. With a more mobile, first-year ice cover, the flaw-leads might be larger or open more frequently, thus producing larger net quantities of sea ice. More importantly, we suspect that large amounts of open water toward the end of summer will favour the removal of fresh water inventory from the shelves through lateral exchange and upwelling (Carmack and Chapman 2003; Williams et al. 2006). Accordingly, the scales would tip toward convection at the mid-shelf sites, which would place more brine into the haloclines and therefore strengthen largescale stratification in the interior ocean.

All of the above changes imply a more stratified future Arctic Ocean, but this misses what is probably going to be the largest climate signal at decadal or longer scales. Atmospheric circulation over the Arctic Ocean exhibits two dominant modes based on pressure fields (i.e. the Arctic Oscillation (Proshutinsky and Johnson 1997)). These pressure fields lead to storage and release of fresh water, especially in the Beaufort Gyre (Carmack et al. 2008), possibly by altering the individual pathways of river water after it has entered the shelves (McClelland et al. 2012). Storage and release have the capacity to export pulses of fresh water (and ice) to the North
Fig. 8 A satellite-based view of the record minimum in the Arctic Ocean's sea-ice distribution, which occurred on September 16, 2012 (source, http://www.nasa. gov/topics/earth/features/2012seaicemin.html), and the trends in the sea-ice minimum since 1978 (inset). The yellow line shows the average minimum sea-ice extent during the past 30 years

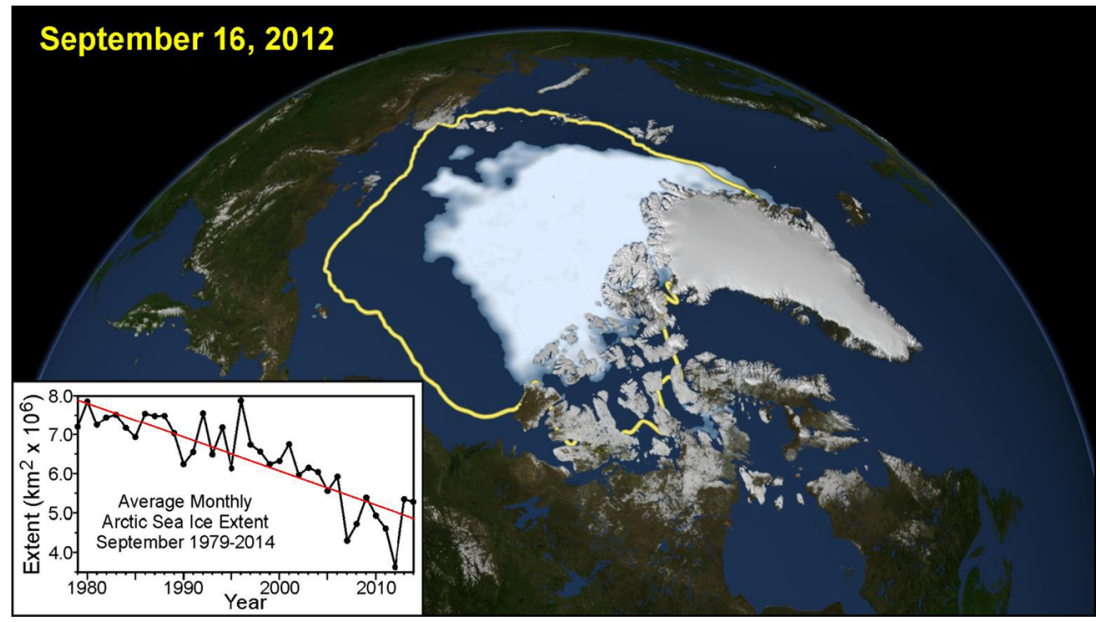


Atlantic Ocean (e.g., the Great Salinity Anomaly, Malmberg and Jónsson 1997). Interestingly, the storage of fresh water has been shown to be as much as $7000 \mathrm{~km}^{3}$ (Polyakov et al. 2013), which approaches the amount required to stall thermohaline circulation if exported rapidly to the North Atlantic (McClelland et al. 2012; Murton et al. 2010). The storage and release of fresh water in the Beaufort Gyre in this way must also have consequences within the Arctic Ocean for nutrient cycles due partly to the effect on stratification and partly to the average wind field in terms of upwelling/ downwelling (e.g. see Carmack and Chapman 2003; Nishino et al. 2008). When the winds blow clockwise around the Arctic basins, they should favour upwelling at the margins, which would enhance shelf productivity, whereas anticlockwise winds suppress upwelling. This hypothesis deserves more attention.

\section{The organic carbon cycle in the Arctic Ocean}

If we measure the organic carbon (OC) in sediments from the Arctic Ocean, we will find pervasive evidence of terrestrial OC (Schubert and Calvert 2001). Based on sedimentary budgets, Stein and Macdonald (2004) estimated that half of the particulate organic carbon (POC) buried in the Arctic's sediments came from land, the other half coming from marine production. Surprisingly, $80 \%$ of the organic carbon that ends up in basin sediments comes from land. In addition to OC, rivers and coastal erosion supply large amounts of inorganic solids (Stein and Macdonald 2004). What this means for the Arctic Ocean is that much of the OC cycle is driven from the ocean margin, almost all of the sediments that sustain burial within the Arctic come from land, and the temporal records in Arctic sediments are strongly terrestrial.

Marine organic carbon $\left(\mathrm{OC}_{\mathrm{Mar}}\right)$ comes from phytoplankton, which requires sunlight and nutrients. Nutrients are supplied by upwelling and mixing, which are certainly affected by stratification, and probably affected by sea-ice cover. A primary difficulty in projecting change in the Arctic Ocean is determining what actually controls the total primary production. The supply of nutrients is the leading contender, but light plays a role by determining where and when the nutrients get used (Carmack et al. 2004). The shelves differ widely in their rates of primary production (Sakshaug 2004), and much of this variation is a product of nutrient supply (Carmack et al. 2006). Inflowing shelves (Chukchi and Barents) have high productivity ( 20 to $>400 \mathrm{~g} \mathrm{C} \mathrm{m}^{-2}$ year $^{-1}$ ) sustained by imports of nutrients from the Pacific and Atlantic oceans, respectively. Interior shelves have more modest productivity $(20-70 \mathrm{~g}$ $\mathrm{C} \mathrm{m}^{-2}$ year $^{-1}$ ) sustained by river inflow, entrainment and upwelling, and the interior Arctic Ocean has the lowest productivity $\left(>11 \mathrm{~g} \mathrm{C} \mathrm{m}^{-2}\right.$ year $\left.^{-1}\right)$, most of which relies on recycled nutrients (Sakshaug 2004).
Each of these regions will change in the production of $\mathrm{OC}_{\mathrm{Mar}}$. Inflowing shelves appear to get more than enough nutrients already. The large-scale inflow of water from the Atlantic and Pacific oceans would seem less vulnerable to change, but a large decline in primary production has been observed in the Chukchi Sea (Yun et al. 2014), which was ascribed to a decrease in the nutrient-rich (Anadyr) component of the Bering Strait inflow and an increase in the relatively fresh and nutrient-poor Siberian Coastal Current, which stratified the surface of the Chukchi Sea and inhibited mixing. We therefore propose that change over the Chukchi Shelf in total production of $\mathrm{OC}_{\mathrm{Mar}}$ will be driven by variability in the supply of nutrients from the Pacific Ocean and variability in fresh water/stratification within the Arctic, which likely will depend on wind-forced circulation and perhaps increased/altered river inflow, but probably not on ice cover.

For the interior shelves, we expect that increased runoff, together with withdrawal of the ice beyond the shelf break, will enhance upwelling/nutrient supply into the surface water (Carmack and Chapman 2003), which will support higher production. The interior ocean, however, will probably become even more stratified, will have a difficult time accessing nutrients, and therefore will not exhibit any great increase in total production despite more ice-free water in summer (e.g. see Dunbar 1993).

Sunlight has a strong role to play in the production and destruction of $\mathrm{OC}$ in the ocean. Like sea ice and river runoff, light undergoes dramatic variation with season, including periods of 24-h daylight and 24-h darkness which can last for months if one goes far enough north. This will not change. Polar sunrise in the spring initiates phytoplankton growth. Water column production occurs first in places where the ice opens early because ice and snow reflect most of the incident visible and ultraviolet radiation ( $85-98 \%$ at sites measured by Belzile et al. 2000), but sunlight can also penetrate first-year ice to support ice algae. On the other hand, ultraviolet radiation damages phytoplankton and drives photochemical reactions that destroy $\mathrm{OC}$ and release $\mathrm{CO}_{2}$.

As sea ice opens earlier, more ocean surface becomes exposed to light and less light gets reflected back into space. At the same time, increasing ozone depletion in the stratosphere (Manney et al. 2011) increases the intensity of UV radiation reaching the ice and the surface ocean. The projected increases in the supply of particles and coloured dissolved organic matter (CDOM) from rivers and coastal erosion will also change the light field. Particles scatter light, largely reflecting it back out of the water. Their influence is generally limited to within river plumes and near land. On the other hand, terrigenous CDOM remains in surface water longer, potentially affecting a large part of the Arctic Ocean (Pavlov et al. 2015). Ice, particles and CDOM shade the water in varying ways depending on the amount and spectral quality of absorption and scattering of radiation. 
It is clear that the underwater light field will change, with more penetration due to the altered sea-ice cover and less penetration due to the enhanced input of CDOM and particulates from shore; the balance between these will vary among locations. On one hand, greater amounts of light would support earlier primary production, and perhaps favour more primary production deeper in the water column, but it may not have much long-term effect on total production if this is controlled by nutrient supply. On the other hand, less penetration near shore will limit primary production to the surface water. Increased incident UV will augment photochemical reactions, which are not limited by stratification or nutrient supply. But, again, particulates and CDOM from land will play a crucial role in shielding phytoplankton from UV damage. Currently, a concentrated layer of phytoplankton tends to be found at about 40-50 m below the surface of the ocean (deep chlorophyll maximum) where there is a balance between nutrients and light. This region of productivity, whose importance to the Arctic Ocean's carbon cycle is not well quantified, may be among the most vulnerable to light intensity increased by loss of sea ice and decreased by CDOM and particulates (e.g., see Granskog et al. 2007). An unevaluated, but potentially important, consequence of increased UV and CDOM is the photochemical oxidation of the latter to release nitrogen (Bushaw et al. 1996) and iron (Miller and Kester 1994), which would then boost phytoplankton productivity.

There is one very strong possibility for a game-changer in the OC production that involves sea ice. The shift from multiyear ice to first-year ice leads to far more favourable conditions to grow algae at the bottom of the ice. Boetius et al. (2013) measured an increase in amount of organic aggregates (algae) shed from rotting ice; these aggregates rapidly descended to the abyss in the central basins $(\sim 4000 \mathrm{~m})$, where they accounted for a whopping $9 \mathrm{~g} \mathrm{C} \mathrm{m}^{-2}$ of $\mathrm{OC}_{\mathrm{Mar}}$ (cf. historical estimates of $<1 \mathrm{~g} \mathrm{C} \mathrm{m}^{2}$ year $^{-1}$ ). If sustained, the process of shedding mats of fresh organic matter from the ice would 'fix' the presently 'broken' coupling between surface production and deep basin organic particle flux (cf. Honjo et al. 2010). But before rushing to conclusions, it will be important to evaluate whether this process would be sustainable. The problem with a large bottom flux of $\mathrm{OC}$ is that it requires an accompanying flux of $\mathrm{N}$ and $\mathrm{P}$. If nutrient supply limits primary production, then the enhanced loss of nutrients out of the mixed layer might not be replaceable, especially if the interior ocean is becoming more stratified. Presently, we have little idea how the basin will rebalance organic and nutrient cycles with this sort of change.

The primary production story becomes even more interesting if we consider the possible role that iron might play as a limiting factor (Measures 1999; Taylor et al. 2013). The Arctic Ocean presently gets its iron from river input, bottom sediments and dirt entrained into sea ice. If iron controls primary production at certain times and places, as suggested by Taylor et al. (2013), then change in sea-ice climate and enhanced destruction of CDOM by photolysis may assume more importance in the supply of iron to the Arctic Ocean's mixed layer. We know almost nothing about the present iron cycle in the Arctic Ocean or its vulnerability to change.

Terrigenous organic carbon $\left(\mathrm{OC}_{\mathrm{Terr}}\right)$ differs from marine carbon, not only in its composition but also in how it enters the ocean and how climate change will affect its supply to the ocean. Excepting coastal erosion, which is enhanced by a longer open water season and increasing open water area, sea ice will matter hardly at all for changing the inputs of $\mathrm{OC}_{\mathrm{Terr}}$; rather, it will be the demise of land ice (permafrost thaw), change in vegetation in the drainage basins and alteration of river hydrology that will matter. The Arctic Ocean's drainage basins lie directly in the path of large change associated with permafrost thaw. Terrestrial ecosystems of the Arctic contain approximately $40 \%$ of the world's near-surface labile soil carbon inventory (McGuire et al. 2009), with $1.7 \times 10^{15} \mathrm{~kg}$ of organic carbon stored in the permafrost (Schuur et al. 2013). This is an enormous $\mathrm{OC}_{\text {Terr }}$ reservoir and, if released, some of it would end up in the Arctic Ocean. Stein and Macdonald (2004) proposed that $\mathrm{OC}_{\mathrm{Terr}}$ preserved in the sediments presently accumulating the Arctic Ocean amounted to $4.4 \times 10^{6}$ tonnes year $^{-1}$ compared to $2.2 \times 10^{6}$ tonnes year $^{-1}$ of $\mathrm{OC}_{\text {Mar }}$ Clearly, the records written in Arctic sediments by preserved biomarkers will say as much about the changes in supply of $\mathrm{OC}_{\mathrm{Terr}}$ as changes in $\mathrm{OC}_{\mathrm{Mar}}$. Stein and Macdonald (2004) proposed that about $350 \times 10^{6}$ tonnes year $^{-1}$ of $\mathrm{OC}_{\mathrm{Mar}}$ was produced within the upper ocean compared to $\sim 13 \times 10^{6}$ tonnes year ${ }^{-1}$ of $\mathrm{OC}_{\mathrm{Terr}}$ supplied around the margin, which is a far different picture than painted by the burial fluxes. Consequently, it will require a much larger change in the supply of $\mathrm{OC}_{\mathrm{Mar}}$ vs. $\mathrm{OC}_{\mathrm{Terr}}$ to make a noticeable difference in buried OC. The $\mathrm{OC}_{\text {Terr }}$ supply appears headed for some large changes (Hinzman et al. 2005; McGuire et al. 2009; Schuur et al. 2013) that may already have begun (Feng et al. 2013; Sánchez-Garcia et al. 2011; Sanchez-Garcia et al. 2014; Vonk et al. 2012). Carbon-14 dating suggests that POC ${ }_{\text {Terr }}$ introduced to the Arctic Ocean is old (over 5000 years) carbon eroded out of river banks (e.g. Guo et al. 2012; Guo and Macdonald 2006), whereas the dissolved $\mathrm{OC}_{\mathrm{Terr}}$ is younger material ( $<300 \mathrm{yrs})$. Both of these OC supplies are changing, partly as a direct consequence of permafrost thaw leading to a deeper active layer and partly because of vegetation changes. It seems likely, therefore, that large-scale change in the Arctic's drainage basins will be written clearly in composition of the old POC accumulating in the Arctic Ocean basin sediments.

Rapid change is already occurring in the Arctic's terrestrial environment (e.g. Rowland et al. 2010; Sanchez-Garcia et al. 2014; Smol and Douglas 2007) and larger changes loom (Schuur et al. 2013). It is likely that the Arctic Ocean will witness a large increase in the $\mathrm{OC}_{\text {Terr }}$ that it receives. A large 
portion of that increase will likely be a consequence of accelerated coastal erosion, which is facilitated by sea-level rise together with the complete absence of sea ice in late summer/fall over the shelves. The consequent open water and large fetch means that autumn storms produce big waves and storm surges (Lantuit et al. 2012). Recently, Vonk et al. (2012) presented data from the East Siberian Sea that suggested the supply of $\mathrm{OC}_{\text {Terr }}$ might be far larger than previously thought or, alternatively, accelerated release of $\mathrm{OC}_{\text {Terr }}$ has already begun. For the East Siberian shelf alone, they suggested that $44 \times 10^{6}$ tonnes of $\mathrm{OC}_{\text {Terr }}$ is released annually, of which two thirds is metabolized and one third buried in sediments. The kind of detailed biomarker study that produced these estimates is rare in Arctic studies yet clearly could revolutionize our thinking about the magnitude and fate of OC supplied from the land.

The topics of organic carbon and fresh water lead naturally into ocean acidification (OA), to which the Arctic Ocean appears especially sensitive (AMAP 2013). Although loss of sea-ice cover might accelerate the rate of exchange of $\mathrm{CO}_{2}$, allowing the ocean to catch up with atmospheric loading and thus become more acidified, it is likely that the fresh water content of surface seawater is far more crucial for the Arctic Ocean's sensitivity. Sea-ice melt and precipitation are, in particular, very poorly buffered against $\mathrm{pH}$ change. River water also tends to be poorly buffered compared to seawater such that Arctic Ocean surface water can easily be driven to the point where aragonite will dissolve (AMAP 2013). Aragonite is the solid form of carbonate used by a number of species to make their hard body parts (shells). The crucial point here is that $\mathrm{OA}$ is not strictly about $\mathrm{pH}$, but about change occurring in a buffered 'carbonate system' that includes $\mathrm{H}_{2} \mathrm{CO}_{3}, \mathrm{HCO}_{3}^{-}, \mathrm{CO}_{3}^{--}$(Fig. 9). The metabolism of OC also produces $\mathrm{CO}_{2}$ within the water column, which serves to acidify the seawater in the same way as $\mathrm{CO}_{2}$ added from the atmosphere. Accordingly, large loads of ancient POC $_{\text {Terr }}$ (Vonk et al. 2012) together with larger amounts of sinking algal mats (POCMar, Boetius et al. 2013) lead to bottom waters over the shelves especially vulnerable to acidification in the future. These bottom waters, isolated by stratification, have no way of rapidly shedding their $\mathrm{CO}_{2}$ to the atmosphere. The Arctic Ocean contains many species vulnerable to OA (AMAP 2013).

One other large vulnerability in the Arctic Ocean bears little direct relationship to sea-ice cover. Sediments of the Arctic's shelves contain enormous quantities of methane (100-600 Gt) combined with water to form a solid in sediments (Marín-Moreno et al. 2013). This methane has been stable for millennia within the sediments because it resides at water depths (hydrostatic pressures) and cold temperatures that favour the solid phase. The problem is really with bottomwater temperature. Historically, the bottom waters of shelves have stayed cold, near the freezing point of seawater, because of those ice-related processes supporting the strong stratification. Strong stratification prevents the heat acquired from sunlight in summer from penetrating to depth, and therefore protects the bottom water from warming. But could this change? The warming of the water in the Atlantic layer (Polyakov et al. 2013) could lead to warm bottom water over shelf and slope sediments, but this source of heat bears little relationship to the sea ice. Surface water warmed within the Arctic Ocean because of sea-ice loss, or warmed before it enters the Arctic from the Pacific or Atlantic Oceans, might penetrate more deeply into the water column in late summer (Carmack et al. 2015). The potential warming and destabilization of subsea methane in Arctic shelf regions is worrisome, given the potential to vent this directly to the atmosphere as a gas (Shakhova et al. 2010). Stratification, not sea ice, will be the deciding factor.

\section{Concluding remarks}

Coming back to our original contention that sea ice is not the only bearer of change in the Arctic Ocean, we find that two other system parameters independent of the ice are of crucial importance to how the Arctic Ocean will change: fresh water from runoff and precipitation, and organic matter from land. It
Fig. 9 A schematic diagram showing the carbonate system in the context of Arctic Ocean acidification. Note that terrestrial organic matter may be oxidized to produce $\mathrm{CO}_{2}$ in the water, which has the potential to contribute strongly to acidification in bottom waters

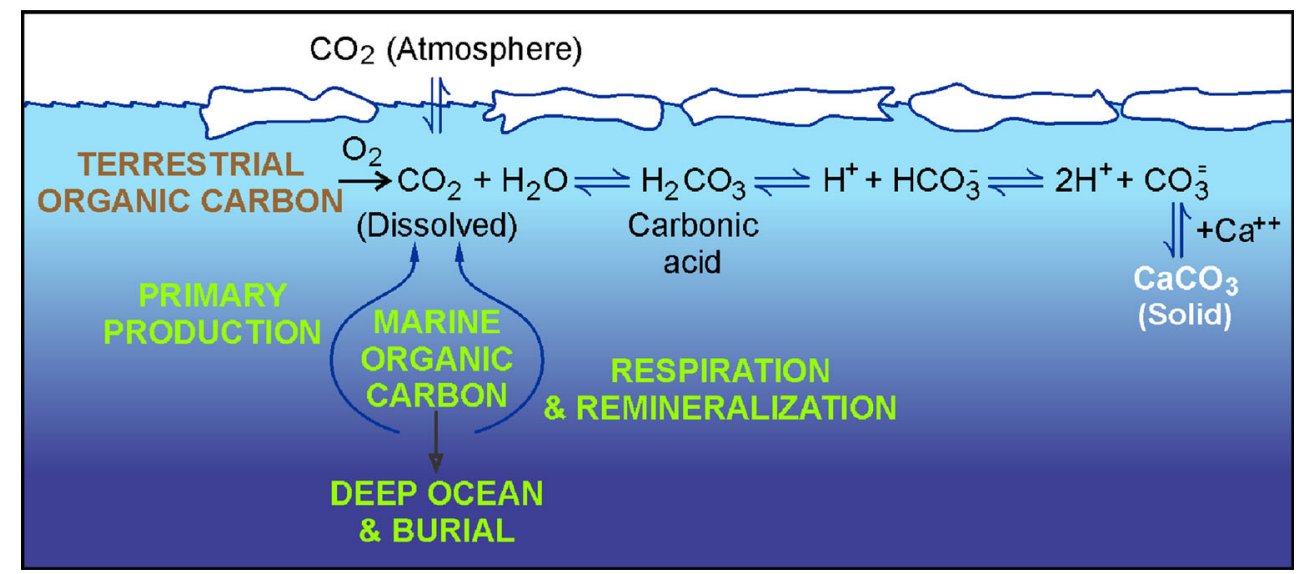


is highly probable that there will be more fresh water in the future Arctic Ocean. This extra fresh water will support more entrainment and an increased supply of nutrients over shelves, but it will also provide a stronger fresh water lid in the interior ocean, particularly in the Beaufort Gyre, which will suppress the vertical resupply of nutrients to the surface. If the stratification of the Arctic Ocean by fresh water controls the total annual primary production, and less so sea-ice cover, then future change in the total primary production will reflect the ocean's response to runoff and precipitation. The ice does get a say; the shift from multi-year ice to seasonal ice is changing the character of sea ice as a habitat, making it more conducive to grow ice algae, allowing widespread development of melt ponds and, perhaps, shedding large algal mats when it rots, thus altering the connection between the surface ocean and the abyss. This latter process may be self-limiting because algal mats must also shed nutrients from the mixed layer. Of all the processes associated with fresh water, the rapid release of stored liquid water and sea ice, made possible by decadal shifts in wind fields (e.g. the Arctic Oscillation), has the greatest potential to alter nutrient and heat cycles within the Arctic Ocean and to export change to the Atlantic Ocean in a form that could impede deep convection. These cycles do not depend entirely on sea-ice cover.

In the organic cycle, the $\mathrm{OC}_{\text {Terr }}$ imported to the Arctic shelves may increase by a large amount, given the enormous size of the Arctic's soil OC reservoir and its vulnerability to permafrost thaw. Erosion of shores and river banks that are poorly bonded and historically held together by ice is likely to lead to rapid and large increase in the terrigenous POC entering the Arctic Ocean (and see Galy et al. 2015). This carbon provides, potentially, a large feedback to atmospheric $\mathrm{CO}_{2}$ depending on what fraction of it becomes metabolized to $\mathrm{CO}_{2}$ rather than buried as $\mathrm{OC}$ in sediments, and therefore is potentially also a key player in Arctic Ocean acidification in shelf bottom waters. Organic biomarkers within arctic sediments will provide an important means to detect change in the Arctic's terrigenous systems. These processes do not depend greatly on sea ice with the exception of coastal erosion, which may strongly accelerate when winds from the north cross wide expanses of open waters prior to delayed ice formation on shelves..

Decreased sea-ice cover, especially decreased multi-year ice, will increase light intensity in the upper ocean. This will play a role on where and when phytoplankton grow, but probably not on the total amount of growth if that is controlled by nutrient supply. On the other hand, increased exposure to UV may damage phytoplankton. Independent of the sea ice, CDOM from land will also play an increasing, and potentially widespread, role in shading the water column and providing biologically available nitrogen and iron through photo-oxidation. The processes of production and destruction of organic matter by light will change, but it remains uncertain how the two processes will rebalance.
Sea-ice climate is changing, and there is a vigorous program observing that change across the entire Arctic Ocean, with a keystone time series contributed by over four decades of satellite-based observations. To understand the other changes underway in the Arctic Ocean requires that we coordinate equally vigorous observations targeting the fresh water and organic systems. Although we have in hand several programs extending over the last decade or so that have begun to tackle a more complete geochemical approach (e.g. the Great Rivers Observatory (http://www.arcticgreatrivers.org/); the Arctic Switchyard Project (http://www.ldeo.columbia.edu/Switchyard); the North Pole Environmental Observatory (http://psc.apl. washington.edu/northpole/); The Nansen and Amundsen Basins Observation System (https://www.aoncadis.org/project/ international_arctic_research_center_iarc__nabos_nansen and_amundsen_basins_observational_system.); Beaufort Gyre Exploration Project (http://www.whoi.edu/beaufortgyre/)), these do not as yet constitute a coordinated attack on the Arctic Ocean as a large-scale system. Nor do these programs universally include a number of measurements that would be key to observing change in the annual net community production and export, both of which likely have important components during times when ships and satellites cannot provide appropriate observations (e.g. see Alkire et al. 2014; Honjo et al. 2014). Geochemical tracers (e.g. stable isotopes, alkalinity and other water properties, organic biomarkers), and a number of sampling approaches (Honjo et al. 2014) to provide insight into these changes, need to be incorporated into coherent and widespread time series that will capture these less-visible changes.

Acknowledgments We thank the many organizations that have supported our work over the years and the community of like-minded individuals who have spent much of their careers trying to make clear what Arctic change really means. In particular, we are grateful to the Northern Contaminants Program, the Arctic Monitoring and Assessment Programme and ArcticNet. We appreciate the constructive comments of two anonymous reviewers who helped to improve the manuscript.

Open AccessThis article is distributed under the terms of the Creative Commons Attribution 4.0 International License (http:// creativecommons.org/licenses/by/4.0/), which permits unrestricted use, distribution, and reproduction in any medium, provided you give appropriate credit to the original author(s) and the source, provide a link to the Creative Commons license, and indicate if changes were made.

\section{References}

Aagaard K, Carmack EC (1989) The role of sea ice and other fresh water in the Arctic circulation. J Geophys Res 94:14,485-414,498

Aagaard K, Swift JH, Carmack EC (1985) Thermohaline circulation in the Arctic Mediterranean seas. J Geophys Res 90:4833-4846

Alkire MB, Lee CM, D’Asaro E, Perry MJ, Briggs N, Cetinic I, Gray A (2014) Net community production and export from Seaglider measurements in the North Atlantic after the spring bloom. J Geophys Res Ocean 119:6121-6139. doi:10.1002/2014JC010105 
AMAP (2013) Arctic Ocean acidification assessment: summary for policymakers. AMAP, Oslo

Anderson DL (1961) Growth rate of sea ice. J Glaciol 3:1170-1172

Belzile C, Johannessen SC, Gosselin M, Demers S, Miller WL (2000) Ultraviolet attenuation by dissolved and particulate constituents of first-year ice during late spring in an Arctic polynya. Limnol Oceanogr 45:1265-1273

Bintanja R, Selten FM (2014) Future increases in Arctic precipitation linked to local evaporation and sea-ice retreat. Nature 509:479482. doi:10.1038/nature 13259

Boetius A et al (2013) Export of algal biomass from the melting Arctic sea ice. Science 339:1430-1432. doi:10.1126/science.1231346

Boyd TJ, Steele M, Muench RD, Gunn JT (2002) Partial recovery of the Arctic Ocean halocline. Geophys Res Lett. doi: 10.1029/ 2001GL014047:2-1-2-4

Broecker WS (2006) Was the younger Dryas triggered by a flood? Science 312:1146-1148

Bushaw KL et al (1996) Photochemical release of biologically available nitrogen from aquatic dissolved organic matter. Nature 381:404-407

Carmack E (2015) Towards quantifying the increasing role of ocean heat in sea ice loss in the new Arctic. Bull Am Meteorol Soc. doi:10. 1175/BAMS-D-13-00177.1

Carmack EC, Chapman DC (2003) Wind-driven shelf/basin exchange on an Arctic shelf: the joint roles of ice cover extent and shelf-break bathymetry. Geophys Res Lett 30:1778

Carmack EC, Macdonald RW, Jasper S (2004) Pelagic phytoplankton productivity on the Canadian shelf of the Beaufort Sea. Mar Ecol Prog Ser 277:37-50

Carmack EC, Barber D, Christensen J, Macdonald RW, Rudels B, Sakshaug E (2006) Climate variability and physical forcing of the food webs and the carbon budget on panarctic shelves. Progress Oceanograph 71:145-181 doi: 1016/j.pocean.2006.10.005

Carmack EC, McLaughlin FA, Yamamoto-Kawai M, Itoh M, Shimada K, Krishfield R, Proshutinsky A (2008) Freshwater storage in the northern ocean and the special role of the Beaufort Gyre. In: Dickson RR, Meincke J, Rhines P (eds) Arctic-Subarctic Ocean fluxes. Springer, Dordrecht, pp 145-169

Dunbar MJ (1993) Hudson Bay has too much fresh water. The Center for Climate and Global Change Research-McGill University 4:12-13

Feng X et al (2013) Differential mobilization of terrestrial carbon pools in Eurasian Arctic river basins. Proc Natl Acad Sci 110:14168-14173

Francis JA et al (2009) An arctic hydrological system in transition: feedbacks and impacts on terrestrial, marine and human life. J Geophys Res 114:G04019. doi:10.1029/2008JG000902

Galy V, Peucker-Ehrenbrink B, Eglinton TI (2015) Global carbon export from the terrestrial biosphere controlled by erosion. Nature 521: 204-207. doi:10.1038/nature 14400

Gordon DC et al. (1996) LOICZ biogeochemical modelling guidelines. LOICZ Reports \& Studies no. 5, 96 pp, Texel

Granskog MA, Macdonald RW, Mundy CJ, Barber DG (2007) Distribution, characteristics and potential impacts of chromophoric dissolved organic matter (CDOM) in the Hudson Strait and the Hudson Bay. Cont Shelf Res 27:2032-2050

Guo L, Macdonald RW (2006) Source and transport of terrigenous organic matter in the upper Yukon River: evidence from isotope $\left({ }^{13} \mathrm{C}\right.$, ${ }^{14} \mathrm{C}$ and $\left.{ }^{15} \mathrm{~N}\right)$ composition of dissolved, colloidal and particulate phases. Glob Biogeochem Cycles 20:GB2011. doi:10.1029/ 2005GB002593

Guo L, Cai Y, Belzile C, Macdonald RW (2012) Sources and export fluxes of organic and inorganic carbon and nutrient species from the seasonally ice covered Yukon River. Biogeochemistry 107: 187-206. doi:10.1007/s10533-010-9545-Z

Hinzman L et al (2005) Evidence and implications of recent climate change in terrestrial regions of the Arctic. Clim Chang 72:251-298
Honjo S et al (2010) Biological pump processes in the cryopelagic and hemipelagic Arctic Ocean: Canada Basin and Chukchi Rise. Prog Oceanogr 85:137-170. doi:10.1016/j.pocean.2010.02.009

Honjo S et al (2014) Understanding the role of the biological pump in the global carbon cycle: an imperative for ocean science. Oceanography 27:10-16. doi:10.5670/oceanog.2014.78

Johnson MA, Polyakov IV (2001) The Laptev Sea as a source for recent Arctic Ocean salinity changes. Geophys Res Lett 28:2017-2020

Kerr RA (2012) Ice-free Arctic sea may be years, not decades, away. Science 337:1591

Kwok R, Untersteiner N (2011) The thinning of Arctic sea ice. Phys Today 64:36-41

Lantuit $\mathrm{H}$ et al (2012) The Arctic coastal dynamics database: a new classification scheme and statistics on Arctic permafrost coastlines. Estuar Coasts 35:383-400. doi:10.1007/s12237-010-9362-6

Laxon SW et al (2013) CryoSat-2 estimates of Arctic sea ice thickness and volume. Geophys Res Lett 40:732-737. doi:10.1002/grl.50193

Lewis EL, Jones EP, Lemke P, Prowse TD, Wadhams P (2000) The freshwater budget of the Arctic Ocean Environmental Securityvol. 70. NATO science series. Kluwer Academic, London

Macdonald RW (2000) Arctic estuaries and ice: a positive-negative estuarine couple. In: Lewis EL (ed) The freshwater budget of the Arctic Ocean. NATO, ASI Series, pp 383-407

Macdonald RW, Carmack EC, Wallace DWR (1993) Tritium and radiocarbon dating of Canada Basin deep waters. Science 259:103-104

Macdonald RW, Carmack EC, McLaughlin FA, Falkner KK, Swift JH (1999) Connections among ice, runoff and atmospheric forcing in the Beaufort Gyre. Geophys Res Lett 26:2223-2226

Macdonald RW, Harner T, Fyfe J (2005) Recent climate change in the Canadian Arctic and its impact on contaminant pathways. Sci Total Environ 342:5-86

Macdonald RW, Anderson LG, Christensen JP, Miller LA, Semiletov IP, Stein R (2010) The Arctic Ocean: budgets and fluxes. In: Liu KK, Atkinson L, Quinones R, Talaue-McManus L (eds) Carbon and nutrient fluxes in continental margins: a global synthesis, The IGBP series. Springer, Berlin, pp 290-303

Malmberg S-A, Jónsson S (1997) Timing of deep convection in the Greenland and Iceland seas. ICES J Mar Sci 54:300-309

Manney GL et al (2011) Unprecedented Arctic ozone loss in 2011. Nature 478:469-U465. doi:10.1038/nature10556

Marín-Moreno H, Minshull TA, Westbrook GK, Sinha B, Sarkar S (2013) The response of methane hydrate beneath the seabed offshore Svalbard to ocean warming during the next three centuries. Geophys Res Lett 40:5159-51633 doi:10.1002/grl.50985, 201

Martin S, Munoz E, Drucker R (1992) The effect of severe storms on the ice cover of the Northern Tatarskiy Strait. J Geophys Res 97:1775317764

McClelland JW, Déry S, Peterson BJ, Holmes RM, Wood E (2006) A pan-Arctic evaluation of changes in river discharge during the latter half of the 20th century. Geophys Res Lett 33:L06715. doi:10.1029/ 2006G1025753

McClelland JW, Holmes RM, Dunton KH, Macdonald RW (2012) The Arctic Ocean estuary. Estuar Coasts 35:353-368. doi:10.1007/ s12237-010-9357-3

McGuire AD et al (2009) Sensitivity of the carbon cycle in the Arctic to climate change. Ecol Monogr 79:523-555

Measures CI (1999) The role of entrained sediments in sea ice in the distribution of aluminium and iron in the surface waters of the Arctic Ocean. Mar Chem 68:59-70

Miller WL, Kester D (1994) Photochemical iron reduction and iron bioavailability in seawater. J Mar Res 52:325-343

Murton JB, Bateman MD, Dallimore SD, Teller JJ, Yang Z (2010) Identification of younger Dryas outburst flood path from Lake Agassiz to the Arctic Ocean. Nature 464:740-743. doi:10.1038/ nature 08954 
Nishino S, Shimada K, Itoh M, Yamamoto-Kawai M, Chiba S (2008) East-west differences in water mass, nutrient, and chlorophyll a distributions in the sea ice reduction region of the western Arctic Ocean. J Geophys Res-Oceans 113 doi:10.1029/2007jc004666

Östlund HG (1982) The residence time of the freshwater component in the Arctic Ocean. J Geophys Res 87:2035-2043

Pavlov AK, Granskog MA, Stedmon CA, Ivanov BV, Hudson SR, FalkPetersen S (2015) Contrasting optical properties of surface waters across the Fram Strait and its potential biological implications. J Mar Syst 143:62-72. doi:10.1016/j.jmarsys.2014.11.001

Peterson BJ et al (2002) Increasing river discharge to the Arctic. Ocean Sci 298:2171-2173

Polyakov IV, Bhatt US, Walsh JE, Abrahamsen EP, Pnyushkov AV, Wassmann PF (2013) Recent oceanic changes in the Arctic in the context of long-term observations. Ecol Appl 23:1745-1764

Post E et al (2013) Ecological consequences of sea-ice decline. Science 341:519-524. doi:10.1126/science. 1235225

Proshutinsky AY, Johnson MA (1997) Two circulation regimes of the wind-driven Arctic Ocean. J Geophys Res 102:12493-12514

Rabe B et al (2011) An assessment of Arctic Ocean freshwater content changes from the 1990s to the 2006-2008 period. Deep-Sea Res I 58:173-175. doi:10.1016/j.dsr.2010.12.002

Rothrock DA, Percival DB, Wensnahan M (2008) The decline in arctic sea-ice thickness: separating the spatial, annual, and interannual variability in a quarter century of submarine data. J Geophys Res 113 doi: 10.1029/2007JC004252

Rowland JC et al (2010) Arctic landscapes in transition: responses to thawing permafrost. EOS Trans, Am Geophys Union 91:229-230

Rudels B (2015) Arctic Ocean circulation, processes and water masses: a description of observations and ideas with focus on the period prior to the International Polar Year 2007-2009. Prog Oceanogr 132:2267. doi:10.1016/j.pocean.2013.11.006

Sakshaug E (2004) Primary and secondary production in the Arctic seas. In: Stein R, Macdonald RW (eds) The organic carbon cycle in the Arctic Ocean, vol chapter 3. Springer, Heidelberg, pp 57-81

Sánchez-Garcia L et al (2011) Inventories and behavior of particulate organic carbon in the Laptev and East Siberian seas. Glob Biogeochem Cycles 25:GB2007

Sánchez-Garcia L, Vonk JE, Charkin A, Kosmach D, Dudarev O, Semiletov I, Gustafsson O (2014) Characterisation of three regimes of collapsing Arctic ice complex deposits on the SE Laptev Sea coast using biomarkers and dual carbon isotopes. Permafr Periglac Process 25:172-183. doi:10.1002/ppp.1815

Schindler DW, Smol JP (2006) Cumulative effects of climate warming and other human on freshwaters of Arctic and subarctic freshwaters of North America. Ambio 35:160-168

Schlosser P, Bauch D, Fairbanks R, Bönisch G (1994a) Arctic river-runoff: mean residence time on the shelves and in the halocline. DeepSea Res I 41:1053-1068

Schlosser P, Kromer B, Östlund G, Ekwurzel B, Bönisch G, Loosli HH, Furtschert R (1994b) On the ${ }^{14} \mathrm{C}$ and ${ }^{39} \mathrm{Ar}$ distribution in the central Arctic Ocean: implications for deep water formation. Radiocarbon $36: 327-345$

Schubert CJ, Calvert SE (2001) Nitrogen and carbon isotopic composition of marine and terrestrial organic matter in Arctic Ocean sediments: implications for nutrient utilization and organic matter composition. Deep-Sea Res I 48:789-810

Schuur EAG et al (2013) Expert assessment of vulnerability of permafrost carbon to climate change. Clim Change. doi:10.1007/s10584-0130730-7

Serreze MC et al (2006) The large-scale freshwater cycle of the Arctic. J Geophys Res 111:C11010. doi:10.1029/2005JC003424

Shakhova NE, Semiletov I, Salyuk A, Yusupov V, Kosmach D, Gustafsson O (2010) Extensive methane venting to the atmosphere from sediments of the East Siberian Arctic shelf. Science 327:12461250. doi:10.1126/sceince.1182221

Shimada K et al. (2006) Pacific Ocean inflow: influence on catastrophic reduction of sea ice cover in the Arctic Ocean. Geophys Res Lett 33: doi: 10.1029/2005GL025624

Smith LC, Sheng Y, MacDonald GM, Hinzman LD (2005) Disappearing Arctic lakes. Science 308:1429

Smith JN, McLaughlin FA, Smethie WM, Moran SB, Lepore K (2011) Iodine-129, ${ }^{137} \mathrm{Cs}$, and CFC-11 tracer transit time distributions in the Arctic Ocean. J Geophys Res 116 doi: 10.1029/2010JC006471

Smol JP, Douglas MSV (2007) Crossing the final ecological threshold in high Arctic ponds. Proc Natl Acad Sci. doi:10.1073/pnas. 0702777104:12395[--]12397

Stein R, Macdonald RW (2004) Chapter 8. Organic carbon budget: Arctic Ocean versus global ocean. In: Stein R, Macdonald RW (eds) The Arctic Ocean organic carbon cycle: present and past. Springer, Berlin, pp 315-322

Stroeve JC, Kattsov V, Barrett A, Serreze M, Pavlova T, Holland M, Meier WN (2012) Trends in Arctic sea ice extent from CMIP5, CMIP3 and observations. Geophys Res Lett 39:L16502. doi:10. 1029/2012GL052676

Taylor RL, Semeniuk DM, Payne CD, Zhou J, Tremblay JE, Cullen JT, Maldonado MT (2013) Colimitation by light, nitrate, and iron in the Beaufort Sea in late summer. J Geophys Res-Oceans 118:3260 3277. doi:10.1002/jgrc. 20244

Vonk JE et al (2012) Activation of old carbon by erosion of coastal and subsea permafrost in Arctic Siberia. Nature 489:137-140. doi:10. 1038/nature11392

Walsh JE (1991) The Arctic as a bellwether. Nature 352:19-20

Walsh JE, Overland JE, Groisman PY, Rudolf B (2011) Ongoing climate change in the Arctic. Ambio 40:6-16. doi:10.1007/s13280-0110211-Z

Wijffels SE, Schmitt RW, Bryden HL, Stigebrandt A (1992) Transport of freshwater by the oceans. J Phys Oceanogr 22:155-162

Williams WJ, Carmack EC, Shimada K, Melling H, Aagaard K, Macdonald RW, Ingram RG (2006) Joint effects of wind and ice motion in forcing upwelling in Mackenzie Trough. Beaufort Sea Continent Shelf Res 26:2352-2366. doi:10.1016/j.csr.2006.06.012

Yamamoto-Kawai M, McLaughlin FA, Carmack EC, Nishino S, Shimada K (2008) Freshwater budget of the Canada Basin, Arctic Ocean, from salinity, $\delta^{18} \mathrm{O}$, and nutrients. J Geophys Res 113 doi: 10 . 1029/2006JC003858

Yun M-S, Whitledge TE, Gong M, Lee SH (2014) Low primary production in the Chukchi Sea shelf (2009). Cont Shelf Res 76:1-11. doi: 10.1016/j.csr.2014.01.001 